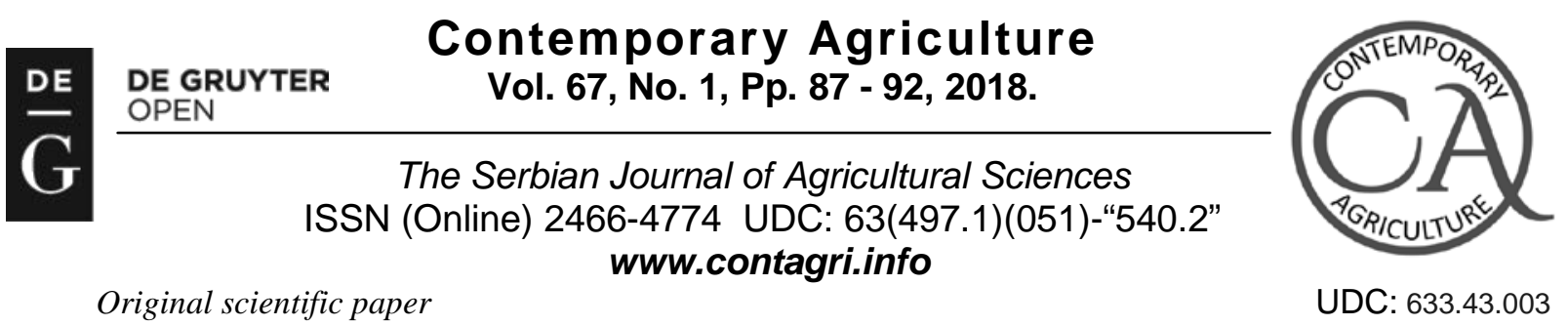

DOI: $10.2478 /$ contagri-2018-0013

\title{
BIURET AND BRADFORD METHODS SUITABILITY FOR PROTEIN QUANTIFICATION IN RAPESEED MEAL*
}

\author{
Hristo KALAYDZHIEV ${ }^{1}$, Petya IVANOVA ${ }^{1}$, Galina UZUNOVA ${ }^{2}$, Ivan MANOLOV ${ }^{3}$, Vesela \\ CHALOVA ${ }^{\star 1}$
}

\begin{abstract}
Summary: Being attractive for insects, non-genetically modified rapeseed is valuable for maintaining environmental biodiversity. Primarily, the rapeseed is an important industrial crop which is used for production of vegetable oil. Oil extraction from rapeseeds results in the generation of substantial amounts of rapeseed meal which is used either as a protein rich feed additive or as a source for preparation of protein containing ingredients for food industry. Both applications require frequent evaluation of protein content. Although Kjeldahl method is considered standard, it is not appropriate for routine evaluation of protein content in protein extracts. The aim of the study was to evaluate suitability of biuret and Bradford methods for protein quantification in rapeseed meal extracts. After consecutive triple extraction of proteins with water, 5\% NaCl, $70 \%$ ethyl alcohol and $0.1 \mathrm{~N} \mathrm{NaOH}$, protein evaluation of each albumin, globulin, prolamin and glutelin extraction aliquot demonstrated overall lower protein content by Bradford method compared to biuret method. The most pronounced differences in protein content were observed with prolamin fraction where three fold higher protein concentrations in each extraction aliquot was observed when biuret method was applied for the evaluation. Comparative quantification of the total protein of each of the four fractions followed a similar trend of lower protein content evaluation by Bradford method. Overall results indicated biuret method as more suitable for protein quantification in rapeseed meal extracts which was confirmed by comparison with data obtained by Kjeldahl method.
\end{abstract}

Key words: rapeseed meal, protein quantification, spectrophotometric methods, Kjeldahl method.

\section{INTRODUCTION}

Rapeseed is a major technical plant which cultivation worldwide achieved steady growth over the last 20 years. After surpassing cotton production at the beginning of 2000, it became the second most cultivated oilseed crop after soybean (Carré and Pouzet, 2014). The largest producers are China, India, Canada and the European Union. Rapeseed/canola oil is used either for food purposes or biodiesel production as the later accounts for 57-70\% of the total biofuel generation in the EU (Zentková and Cvengrošová, 2013). Due to increased interest to rapeseed oil, the worldwide production of rapeseeds has been predicted to enhance in near future (Carré and Pouzet, 2014).

Beside economic impact, rapeseed is important for maintaining natural biodiversity. The bright yellow color of the flower and shallow allocation of nectar attract various bees, flies, and butterflies (Kunin, 1997; Pudasaini et al., 2015). After studying rapeseed insect diversity, Milovac et al. (2012) reported a total of 8,384 specimens from 11 insect orders with prevailing specimens belonging to Diptera and Coleoptera. Divers groups of bacteria including Bacillus, Fhvobucterium, Micrococcus and Rathayibacter have been observed in association with canola plants roots as well (Germida et al., 1998).

The extraction of oil from rapeseeds results in generation of rapeseed meal, a by-product, which amount may reach up to $48 \%$ of the total quantity of rapeseeds used (Ivanova, 2012). In the international production of defatted

\footnotetext{
${ }^{1}$ Hristo Kalaydzhiev, MS, Doctoral Student, Petya Ivanova, PhD, Assistant Professor, Vesela Chalova, PhD, Associate Professor, University of Food Technologies, Department of Biochemistry and Molecular Biology, 26 Maritsa Blvd, Plovdiv 4002, Bulgaria ${ }^{2}$ Galina Uzunova, PhD, Associated Profesor, University of Food Technologies, Department of Technology of Tobacco, Sugar, and Vegetable Essential Oils, 26 Maritsa Blvd, Plovdiv 4002, Bulgaria

${ }^{3}$ Ivan Manolov, PhD, Full Professor, Agricultural University, Department of Agrochemistry and Soil Science, 12 Mendeleev Str., Plovdiv 4000, Bulgaria

•Corresponding author: e-mail: veselachalova@gmail.com, Tel.: +359 32603855
} 
meals, the rapeseed meal ranks second after the soybean meal. It can be used directly as a protein rich additive in feed industry or as a source for preparation of protein isolates and concentrates (Newkirk, 2009; Tan et al., 2011).

The utilization of the rapeseed meal requires frequent evaluation of protein content because of various reasons which include but are not limited to establishment of nutritive characteristics for proper diet formulation, conformity to regulatory specifications, authentication of protein-rich ingredients or sources (DuPont et al., 2005; Bonfatti et al., 2008). Detailed description of current methods for total protein measurement in food and feed is provided by Moore et al. (2010). Protein quantification by Kjeldahl method is considered standard and reliable. Many international laboratories use it as a reference procedure due to its accuracy regardless of the physical state of the sample (OwusuApenten, 2012). However, the technique is labor-intensive, long lasting and expensive and therefore, it is less applicable for routine and extensive evaluation of protein content. It is especially valid for the production of proteinrich ingredients which include protein extraction and optimization steps resulting in numerous samples for evaluation. Spectrophotometric methods including biuret and Bradford methods are simple, rapid, relatively inexpensive and do not require elaborate equipment which make them suitable for routine analyzes (Owusu-Apenten, 2012). However, their accuracy can be interfered by concomitant compounds such as phenols present in meals (Hortin and Meilinger, 2005; Ivanova et al., 2013). The purpose of this study was to evaluate suitability of biuret and Bradford methods for protein quantification in rapeseed meal extracts.

\section{MATERIAL AND METHODS}

Rapeseed meal sample preparation. Rapeseed meal was provided by a local company (Oliva AD, Polski Trambesh). It was produced from rapeseeds yield 2016 after moisture reduction at $110-115^{\circ} \mathrm{C}$ and oil extraction with hexane at $60-65^{\circ} \mathrm{C}$. The meal was grinded and sifted to collect $0.315 \mathrm{~mm}$ particles. To reduce antinutritional compounds in the protein source, the rapeseed meal was subjected to a 4-step treatment with ethanol (96\%)/water mixture $(65 / 35)$ at a meal to solvent ratio of $25 \%(\mathrm{w} / \mathrm{v})$ for $30 \mathrm{~min}$ at room temperature $\left(23^{\circ} \mathrm{C}\right)$ as described by Chabanon et al. (2007). The residue was collected, dried in air and stored in a closed container for further analyzes. All reagents used were of analytical grade.

Rapeseed protein fractionation. Proteins were sequentially extracted from the ethanol treated rapeseed meal with water, $5 \% \mathrm{NaCl}, 70 \%$ ethyl alcohol and $0.1 \mathrm{~N} \mathrm{NaOH}$ to obtain albumin, globulin, prolamin and glutelin fractions respectively (Tan et al., 2012). Each fractional extraction was repeated three times with decreasing meal/residue to solvent ration from the first to the third extraction as it follows: 1:10, 1:5 and 1:2.5. The extraction aliquots were collected separately for protein quantification. All extractions were performed at room temperature $\left(23^{\circ} \mathrm{C}\right)$ for 30 min under constant agitation.

Protein quantification. Kjeldahl method was used to determine total nitrogen content in the ethanol treated rapeseed meal. The result was multiplied by 6.25 to convert to crude protein (AOAC, 1990). Protein content in extracts was evaluated by biuret (AACC, 1983) and Bradford methods (Bradford, 1976). Bovine serum albumin was used to generate standard curves.

Statistical analysis. All extractions and analyses were performed in triplicate. Presented results are averaged means \pm standard deviation (SD). Data were analyzed by one-way analysis of variance (ANOVA) using Statgraphics Centurion statistical program (version XVI, 2009) (Stat Point Technologies, Ins., Warrenton, VA, USA). Mean differences were established by Fisher's least significant difference test for paired comparison with a significance level $\alpha=0.05$.

\section{RESULTS}

Protein content of each rapeseed fraction was significantly higher $(\mathrm{P}<0.05)$ when evaluated by biuret method (Fig. 1). The highest difference (more than 3-folds) was established with prolamin fraction followed by that of the globulins. Although still significant, less than 1.5-fold difference in protein contents measured by the two methods was observed with glutelin fraction. 


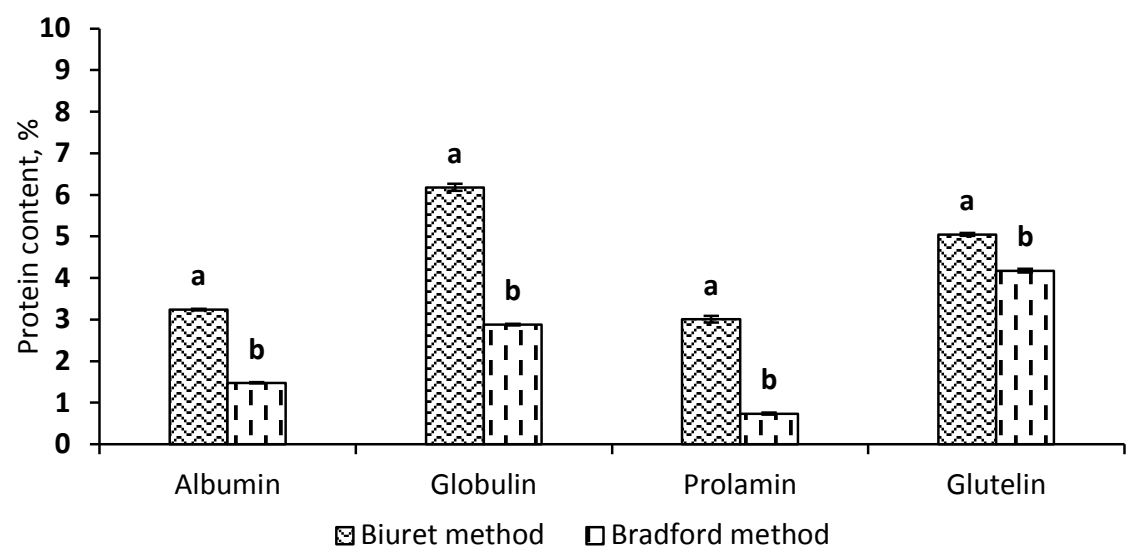

Figure 1. Protein content of ethanol treated rapeseed meal protein fractions evaluated by biuret and Bradford methods

${ }^{\mathrm{a}-\mathrm{b}}$ Values with different superscripts differ significantly $(\mathrm{P}<0.5)$

Similar trend was observed after evaluation of the protein content of each extraction aliquot of a fraction (Table 1). The most remarkable discrepancy in protein contents was observed with the second extraction of the prolamin fraction where the protein level estimated by biuret method exceeded more than 6-flods the protein level of the same fraction estimated by Bradford method.

Table 1. Protein content comparison of extraction aliquots during protein fractionation of ethanol treated rapeseed meal proteins

\begin{tabular}{|c|c|c|c|}
\hline \multirow{3}{*}{ Protein fraction } & \multirow{2}{*}{ Extraction No: } & \multicolumn{2}{|c|}{ Protein content, \%* } \\
\cline { 3 - 4 } & & Biuret method & $\begin{array}{c}\text { Bradford } \\
\text { method }\end{array}$ \\
\hline \multirow{3}{*}{ Albumin } & 1 & $2.05 \pm 0.03$ & $0.90 \pm 0.02$ \\
\cline { 2 - 4 } & 2 & $0.81 \pm 0.02$ & $0.38 \pm 0.01$ \\
\cline { 2 - 4 } & 3 & $0.38 \pm 0.02$ & $0.20 \pm 0.01$ \\
\hline \multirow{3}{*}{ Globulin } & 1 & $4.26 \pm 0.08$ & $2.03 \pm 0.01$ \\
\cline { 2 - 4 } & 2 & $1.32 \pm 0.1$ & $0.60 \pm 0.03$ \\
\cline { 2 - 4 } & 3 & $0.61 \pm 0.07$ & $0.25 \pm 0.02$ \\
\hline \multirow{3}{*}{ Prolamin } & 1 & $1.55 \pm 0.16$ & $0.49 \pm 0.04$ \\
\cline { 2 - 4 } & 2 & $1.19 \pm 0.05$ & $0.18 \pm 0.03$ \\
\cline { 2 - 4 } Glutelin & 3 & $0.28 \pm 0.04$ & $0.07 \pm 0.00$ \\
\cline { 2 - 4 } & 2 & $2.23 \pm 0.02$ & $1.91 \pm 0.06$ \\
\cline { 2 - 4 } & 3 & $1.60 \pm 0.07$ & $1.35 \pm 0.04$ \\
\hline
\end{tabular}

*Protein content was calculated on an air-dry matter basis

Results for protein content obtained by Kjeldahl, biuret and Bradford methods differed significantly $(\mathrm{P}<0.05)$. Comparison of the two methods to Kjeldahl measurement demonstrated closer protein estimation of biuret method than the Bradford one (Fig. 2) 


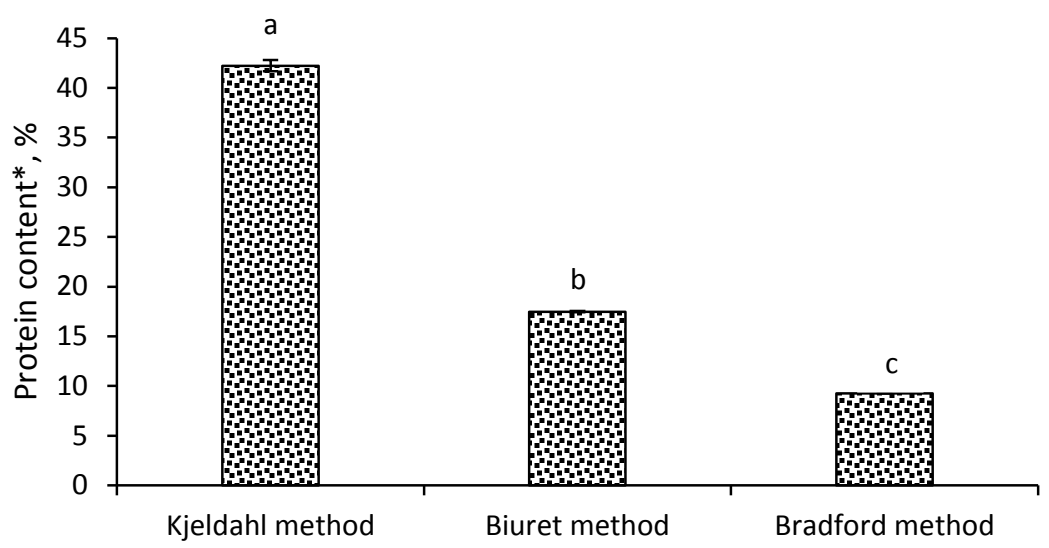

Method used for evaluation

Figure 2. Total protein content of ethanol treated rapeseed meal evaluated by Kjeldahl, biuret and Bradford methods

*Protein contents by biuret and Bradford methods were calculated as a sum of the protein level of each fraction, albumin, globulin, prolamin and glutelin.

${ }^{\mathrm{a}-\mathrm{c}}$ Values with different superscripts differ significantly $(\mathrm{P}<0.5)$

\section{DISCUSSION}

Total content of phenolic acids in canola/rapeseed meal vary from $1.54 \%$ to $1.84 \%$ calculated on a dry matter basis (Naczk et al., 1986). To reduce the level of the phenolic compounds and anti-nutrients such as glucosinolates, which would worsen the quality of subsequently produced rapeseed meal protein- derivatives, the rapeseed meal was subjected to a 4-step ethanol treatment. Previously, by using the same procedure Ivanova et al. (2017) achieved more than four-fold reduction of phenols lowering their level to $0.25 \%$. Most probably, the pretreatment step of the rapeseed meal is the cause for no formation of interfering color at $540 \mathrm{~nm}$ which was noticed when ethanol nontreated rapeseed meal extracts were quantified for proteins by biuret method (data not published). The protein contents of albumin, globulin, prolamin and glutelin fractions of the industrial rapeseed meal evaluated by biuret method (Fig. 1) were close to data reported by Tan et al. (2012) for industrial toasted meal. Similarly, prolamins were found to be the minor fraction of the sample analyzed. The ethanol pre-treatment step used in this study should also be accounted for the relatively low prolamin content reported herein.

Bradford method, when used for protein quantification of either a rapeseed meal protein fraction or an extraction aliquot, led to 2 to 3 folds lower results compared to biuret method. This could be partially explained by the mechanism of interaction of Coomassie Brilliant Blue G250 dye with the analyte. The dye binds to polypeptides with molecular weight greater than $3000 \mathrm{Da}$ as the number of the molecules strongly correlates to the total number of arginine, histidine and lysine (Owusu-Apenten, 2012). According to Klockeman et al. (1997), lysine is the first limiting amino acid in rapeseed protein. In addition, the industrial procedure for oil extraction and rapeseed meal production include enhanced thermal treatment steps which increase the reactivity of $\varepsilon$-amino group of the lysine radical (Kwok et al., 1998). It easily goes into reaction with sugars which reduces lysine radical availability for a subsequent interaction with Coomassie Brilliant Blue G250 dye. According to Brimer et al. (1995), non-enzymatic glycation of proteins interferes with their quantitative evaluation and may result in up to $20 \%$ underestimation when Bradford method is used. Phenolics and other compound from the rapeseed meal may complex with proteins (Aider and Barbana, 2011) which additionally reduces their accessibility to the Coomassie Brilliant Blue G250 dye. Since the interaction between the dye and proteins is electrostatic, differences in the amino acid composition of the fractional proteins as well as those contained in the extraction aliquots is the most probable explanation for the different extent of reduction of the results obtained with Bradford assay (Table 1).

Kjeldahl method for protein quantification is based on sample mineralization followed by determination of total nitrogen content (Owusu-Apenten, 2012). In contrast, biuret and Bradford procedures involve protein extraction steps. However, the choice of extraction procedure highly influences the extent of protein recovery (Pedroche et al., 2004; Tan et al., 2011). In addition, type of the samples should also be accounted for the differences observed among protein yields achieved. For example, Tan et al. (2012) reported lowest protein recovery for industrial toasted meal 
compared to the other samples tested (Australian canola (Brassica napus) meal, mustard (Sinapis alba) meal and pretoasted industrial meal) suggesting high influence of thermal treatment on protein solubility. Therefore, equal protein content measured by Kjeldahl and biuret and Bradford methods applied after protein extraction, cannot be expected. Considering the $40 \%$ protein recovery from industrial toasted meal when Osborne extraction method is used, reported by Tan et al. (2012), total protein content evaluated by biuret method was closer to that of the Kjeldahl method (Fig. 2). Possible inaccuracy of Kjeldahl results may also be assumed due to relatively high non-protein nitrogen compounds in plants (Izhaki, 1993; Fujihara et al., 2001). By using data of total amino acid content of some plant samples from Nigeria, Magomya et al. (2014) calculated specific conversion factors varying from 3.24 to 5.39 which implied considerable overestimation of the protein content if a conversion coefficient of 6.25 is used.

\section{CONCLUSION}

Biuret and Bradford methods are widely used for total protein quantification. Although both spectrophotometric ones, the methods differ in their principles and potential drawbacks. The use of Bradford procedure for the evaluation of protein content of either protein fractions or extraction aliquots resulted in 2 to 3 fold lower results than biuret method. Comparison to Kjeldahl method as well as data reported in literature indicated better suitability of biuret method for determination of the protein content of extracts obtained from industrial rapeseed meal after 4-step aqueous ethanol treatment.

\section{ACKNOWLEDGEMENT}

This research is a part of a doctoral study supported by University of Food Technologies-Plovdiv, Bulgaria

\section{REFERENCES}

AACC: Method 46-15: Crude protein - 5-minute Biuret method for wheat and other grains. Approved methods of the American Association of Cereal Chemists, 8th edition, American Association of Cereal Chemists, St. Paul, MN, USA, 1983.

AIDER, M., BARBANA, C.: Canola proteins: composition, extraction, functional properties, bioactivity, applications as a food ingredient and allergenicity - A practical and critical review. Trends in Food Science \& Technology, 22:21-39, 2011.

AOAC. Official Methods of Analysis, Association of Official Analytical Chemists, Washington, DC, USA, 1990.

BONFATTI, V., GRIGOLETTO, L., CECCHINATO, A., GALLO, L., CARNIER, P.: Validation of a new reversed-phase highperformance liquid chromatography method for separation and quantification of bovine milk protein genetic variants. Journal of Chromatography A, 1195:101-106, 2008.

BRADFORD, M.: A rapid and sensitive for the quantitation of microgram quantities of protein utilizing the principle of proteindye binding. Analytical Biochemistry, 72:248-254, 1976.

CARRÉ, P., POUZET, A.: Rapeseed market, worldwide and in Europe. OCL-Oilseeds and fats, Crop and Lipids, 21:D102-D114, 2014.

CHABANON, G., CHEVAlOT, I., FRAMBOISIER, X., CHENU, S., MARC, I.: Hydrolysis of rapeseed protein isolates: Kinetics, characterization and functional properties of hydrolysates. Process Biochemistry, 42:1419-1428, 2007.

DUPONT, F.M., CHAN, R., LOPEZ, R., VENSEL, W.H.: Sequential extraction and quantitative recovery of gliadins, glutenins, and other proteins from small samples of wheat flour. Journal of Agricultural and Food Chemistry, 53:1575-1584, 2005.

FUJIHARA, S., KASUGA, A., AOYAGI, Y.: Nitrogen-to-protein conversion factors for common vegetables in Japan. Journal of Food Science, 66:412-415, 2001.

GERMIDA, J.J., SICILIANO, S.D., RENATO DE FREITAS, J., SEIB, A.M.: Diversity of root-associated bacteria associated with field-grown canola (Brassica napus L.) and wheat (Triticum aestivum L.). FEMS Microbiology Ecology, 26:43-50, 1998.

HORTIN, G.L., MEILINGER, B.: Cross-reactivity of amino acids and other compounds in the biuret reaction: Interference with urinary peptide measurements. Clinical Chemistry, 51:1411-1419, 2005.

IVANOVA, P., KALAYDZHIEV, H., RUSTAD, T., SILVA, C.L.M. and CHALOVA, V.I.: Comparative biochemical profile of protein-rich products obtained from industrial rapeseed meal. Emirates Journal of Food and Agriculture, 29:170-178, 2017.

IVANOVA, P., KOLEVA, L., CHALOVA, V.: Application of biuret and Bradford methods for quantitative determination of proteins in sunflower products. Scientific Works of University of Food Technologies-Plovdiv, LX:694-699, 2013.

IVANOVA, R.: Rapeseed - The Culture of Present and Future. Videnov \& Son, Sofia, Bulgaria, 2012.

IZHAKI, I.: Influence of nonprotein nitrogen on estimation of protein from total nitrogen in fleshy fruits. Journal of Chemical Ecology, 19:2605-2615, 1993.

KLOCKEMAN, D.M., TOLEDO, R., SIMS, K.A.: Isolation and characterization of defatted canola meal protein. Journal of Agricultural and Food Chemistry, 45:3867-3870, 1997.

KUNIN,W.E.: Population size and density effects in pollination: pollinator foraging and plant reproductive uccess in experimental arrays of Brassica kaber. Journal of Ecology, 85:225-234, 1997.

KWOK, K., SHIU, Y., YEUNG, C., NIRANJAN, K.: Effect of thermal processing on available lysine, thiamine and riboflavin content in soymilk. Journal of the Science of Food and Agriculture, 77:473-478, 1998. 
MAGOMYA, A.M., KUBMARAWA, D., NDAHI, J.A., YEBPELLA, G.G.: Determination of plant proteins via the Kjeldahl method and amino acid analysis: a comparative study. International Journal of Scientific \& Technology Research, 3:68-72, 2014. MILOVAC, Ž., KEREŠI, T., PEŠIĆ, S., JEROMELA, A.M., MARINKOVIĆ, R. and MITROVIĆ, P.: Biodiversity of rapeseed insects. International Conference on BioScience: Biotechnology and Biodiversity, Novi Sad, Serbia, 38-41, 2012.

MOORE, J.C., DEVRIES, J.W., LIPP, M., GRIFFITHS, J.C. and ABERNETHY, D.R.: Total protein methods and their potential utility to reduce the risk of food protein adulteration. Comprehensive Reviews in Food Science and Food Safety, 9:330-357, 2010.

NACZK, M., DIOSADY, L.L. and RUBIN, L.J.: The phytate and complex phenol content of meals produced by alkanol ammonia hexane extraction of canola. Lebensmittel-Wissenschaft \& Technologie, 19:13-16, 1986.

NEWKIRK, R.: Canola meal: Feed industry guide. 2009, www.canolacouncil.org

OWUSU-APENTEN, R.K.: Food Protein Analysis: Quantitative Effects on Processing. Marcel Dekker, Inc, New York, NY, 2002.

PEDROCHE, J., YUST, M.M., LQARI, H., GIRÓN-CALLE, J., ALAIZ, M., VIOQUE, J., MILLÁN, F.: Brassica carinata protein isolates: chemical composition, protein characterization and improvement of functional properties by protein hydrolysis. Food Chemistry, 88:337-346, 2004.

PUDASAINI, R., THAPA, R.B., CHAUDHARY, N.K., TIWARI, S.: Insect pollinators' diversity of rapeseed (Brassica campestris var. toria) in Chitwan, Nepal. Journal of the Institute of Agriculture and Animal Science, 33-34:73-78, 2015.

TAN, S.H., MAILER, R.J., BLANCHARD, C.L., AGBOOLA, S.O.: Canola proteins for human consumption: extraction, profile, and functional properties. Journal of Food Science, 76:R16-R28, 2011.

TAN, S., BLANCHARD, C., MAILER, R., AGBOOLA, S.: Extraction and residual antinutritional components in protein fractions of Brassica napus and Sinapis alba oil-free meals. Protein Science, 21 (Supp.1):75-76, 2012.

ZENTKOVÁ, I., CVENGROŠOVÁ, E.: The utilization of rapeseed for biofuels production in the EU. Visegrad Journal on Bioeconomy and Sustainable Development, 2(1):11-14, 2013.

Received / Primljen: 08.06.2017.

Accepted / Prihvaćen: 24.12.2017. 